\title{
IMPLEMENTASI SISTEM INFORMASI PENGOLAHAN DATA MENGGUNAKAN TEKNOLOGI BLOCKCHAIN PADA : DATA KABUPATEN KOTA KENDAL
}

\author{
Umar Faiz Ubaidillah ${ }^{1^{*}}$, Hari Murti ${ }^{2}$ \\ Program Studi Sistem Informasi, Universitas Stikubank Semarang, Kota Semarang 1,2 \\ e-mail: ufaiz50@gmail.com ${ }^{1}$, harimurti@edu.unisbank.ac.id ${ }^{2}$
}

\begin{abstract}
Abstrak
Blockchain merupakan salah satu teknologi yang bisa digunakan dalam pengolahan data, teknologi blockchain memiliki konsep desentralisasi dengan ciri khas transparan dan aman. Blockchain merupukan rantai block yang mana setiap block terhubung dengan fungsi hash yang berjalan satu arah, lalu dalam setiap block terdapat sebuah data transaksi atau lebih. Dengan memanfaatkan teknologi blockchain dalam pengolahan data, maka dapa membantu sistem untuk membuat data lebih aman dan juga transparan. Dikarenakan maraknya tindakan kejahatan dunia maya pada kasus manipulasi data yang merugikan perorangan atau kelompok, maka tindakan keamanan data perlu dilakukan. Pada penlitian kali ini menggunakan metode prototyping sebagai metode penelitian dan pengembangan system, yang mana metode prototyping merupakan metode yang paling cepat dalam pembangunan sebuah sistem. Implementasi teknologi blockchain untuk pengolahan data ini mengambil objek penelitan rekap data pemerintah kota Kendal dengan menghasilkan sistem aplikasi yang berjalan sesuai yang diharapkan yaitu sistem bisa melakukan keamanan data pada Kabupaten Kota Kendal, serta melakukan transparansi data sehingga data informasi pemerintah kota Kendal bisa di ketahui warga Kota Kendal dan data lebih terpercaya.
\end{abstract}

Kata kunci : Blockchain; Fungsi Hash; Algoritma SHA-256; Javascript

\begin{abstract}
Blockchain is a technology that can be used in data processing, blockchain technology has a decentralized concept with characteristics of being transparent and secure. Blockchain is a block chain where each block is connected to a hash function that runs in one direction, then in each block there is a transaction data or more. By utilizing blockchain technology in data processing, it can help the system to make data safer and also transparent. Due to rampant cybercrime in cases of data manipulation that harm individuals or groups, data security measures need to be taken. This research uses the prototyping method as a system research and development method, where the prototyping method is the fastest method in building a system. The implementation of blockchain technology for data processing takes the object of researching the Kendal city government data recap by producing an application system that runs as expected, namely the system can perform data security in Kendal City Regency, and perform data transparency so that the information data of the Kendal city government can be known by residents and reliable data.
\end{abstract}

Keywords : Blockchain; Hash Function; SHA-256 Algorithm; Javascript 


\section{PENDAHULUAN}

Berdasarkan dari pemahan revolusi industri 4.0 dimana memanfaatkan teknologi dalam cara kerja sebuah organisasi, maka teknologi sangat dibutuhkan untuk menciptakan sebuah organisasi yang efektif dan efesien. Blockchain merupakan sebuah teknologi yang bisa digunakan untuk pengolahan data, yang dalam pengertiannya Blockchain merupakan sebuah teknologi yang berbasis block untuk menyimpan data, yang mana dalam sebuah block memiliki teknik enkripsi fungsi hash sebagai tanda sebuah block dan juga penghubung antara block. Dengan kata lain blockchain merupakan sebuah database terdistribusi dengan keamanan data tanpa adanya manipulasi dalam sebuah block.

Pada bidang ekonomi maupun pengolahan data lain yang melibatkan suatu organisasi maupun instansi milik negara maka keamanan pada setiap sumber daya data organisasi tersebut harus di perhitungkan. Berdasarkan dari penelitianpenelitan sebelumnya yang melibatkan enkripsi dalam keamanan data, enkripsi tersebut masih memiliki celah terhadap adanya manipulasi, ditambah lagi dengan algoritma komputasi yang semakin canggih dan bisa melakukan dekripsi dengan bytecode yang lebih banyak[1]. Maka dari itu teknologi pada penelitan serta pembuatan sistem ini menggunkan teknologi blockchain dengan algoritma SHA-256 untuk melakukan keamanan atau enkripsi pada sumber daya data dalam sebuah organisasi.

Algoritma SHA-256 pada blockchain merupakan algoritma yang sampai saat ini belum bisa dipecahkan karena berjalan satu arah, sehingga penerapan blockchain dianggap sebagai metode yang aman dari manipulasi untuk sistem pengolah data[2]. Serta penerapan teknologi blockchain pada organisasi akan membantu pengolahan data yang ada pada organisasi menjadi efektif, efisien, aman dan transparan. Dengan transaksi dalam teknologi blockchain yang dilakukan secara peer to-peer, sehingga memungkinkan setiap pengguna yang berada pada jaringan blockchain bisa menjadi pengawas sekaligus menjamin keabsahan data dalam block itu sendiri[3].

Di Indonesia, teknologi Blockchain memiliki sedikit pengembang dan hanya sedikit organisasi yang berani melakukan implementasi teknologi ini ke organisasi mereka. Teknologi Blockchain bisa digunakan untuk pengolahan data dari sebuah instansi negara[4], salah satu contohnya adalah pengolahan data informasi di Pemerintah Kota Kendal, yang mana saat ini Pemerintah Kendal memberikan informasi di situs resmi dengan cara melakukan unduh rekap data yang sudah dibuat yang mana itu kurang efektif dan efisien, serta kurang aman. Dengan penerapan teknologi Blockchain untuk pengolahan data informasi di Pemerintah Kendal akan memungkinkan pengolahan data lebih efektif dan efisien serta data informasi dari pemerintah kota kendal akan aman dan transparan. Penerapan teknologi Blockchain juga bisa meningkatkan kepercayaan warga kota kendal.

\section{TINJAUAN PUSTAKA}

2.1 Penelitian Terdahulu yang Terkait Dengan Penelitian

Hasil penelitian yang berjudul Implementasi Sederhana Blockchain dalam penelitiannya menunjukkan bahwa teknologi Blockchain merupakan solusi atas masalah yang terjadi pada sisi ekonomi yaitu masalah pengeluaran ganda, masalah tersebut bisa di atasi dengan adanya fungsi hashing, proof-of-work dan peer-to-peer. Teknologi Blockchain merupakan suatu gambaran dari teknologi yang maju[5]. 
Penggunaan fungsi hashing dan proof-of-work dalam penelitian yang berjudul Implementasi Blockchain di Dunia Kearsipan: Peluang, Tantangan, Solusi atau Masalah Baru? yang ada pada teknologi Blockchain tersebut bisa djuga bisa digunakan untuk bidang kearsipan yang mana bisa mengatasi masalah instrumen of trust . kedua fungsi tersebut bisa digunakan sebagai autentifikasi pada bidang kearsipan[6].

Pada penelitian yang berjudul Implementasi Blockchain: Studi Kasus eVoting memanfaatkan sifat Blockchain yang aman dan transparan yang cocok sebagai metodi penghitung suara. Mulai dari penggunaan transparansi sebagai verifikasi kebenaran data serta keamanan data yang mana data tidak bisa dimanipulasi[7].

\subsection{Blockchain}

Blockchain merupakan teknologi yang diperhitungkan untuk mendukung sebuah organisasi menuju revolusi. Teknologi Blockchain pertama kali dibuat pada tahun 1991 oleh Stuart Haber dan W.Scott Storneta, setelah itu dikembangkan oleh anonim bernama Satoshi Nakamoto pada tahun 2009. Dari pengembangan oleh Satoshi Nakamoto teknologi Blockchain mulai terkenal dengan cryptocurrency pertama yaitu bitcoin. Blockchain sendiri sering disebut dengan buku besar dimana block digambarkan dengan buku besar yang mencatat setiap transaksi. Dalam buku besar tersebut atau block tersebut berisi hash yang dibentuk dari timestamp, transaction dan hash sebelum block tersebut[8].

\section{METODOLOGI PENELITIAN}

Pada metode penelitian menguraikan pemilihan model pengembangan sitem, melakukan Analisa terhadan Sistem yang akan dibuat, serta membuat rancangan
Unified Modeling Language dari sistem yang akan dibuat,

\subsection{Metode Pengembangan Sistem}

Metode untuk mengembangkan sistem ini menggunakan metode prototyping. Prototyping merupakan metode yang paling cepat dalam pembangunan sebuah sistem dan biaya yang digunakan menjadi lebih rendah. Metode ini juga memiliki keuntungan dari segi ketepatan dalam menentukan kebutuhan user, dikarenakan user ikut serta dalam membantu pengembangan sistem. Fase-fase dalam pembangunan sistem dengan menggunakan metode prototyping[9]:

1. Analisa Kebutuhan merupakan fase untuk mengidentifikasi semua kebutuhan dari sistem yang akan dibuat dimulai dari software, hardware hingga brainware.

2. Membangun Prototyping, merupakan fase pembangunan prototyping dengan membuat rancangan sementari dari sistem yang berfokus pada penyajian kepada pelanggan.

3. Evaluasi Prototyping merupakan fase untuk mengevaluasi apakah prototyping yang telah dibuat itu sudah sesuai dengan apa yang diharapkan oleh pengguna.

4. Mengkodekan Sistem merupakan fase pembuatan sistem dalam bahasa pemograman setelah Fase evaluasi prototyping telah disetujui.

5. Menguji Sistem merupakan fase untuk melakukan pengujian sistem yang telah di ubah kedalam bahasa pemograman (perangkat lunak)

6. Evaluasi Sistem merupakan fase untuk perangkat lunak yang sudah siap akan di evaluasi oleh pengguna apakah sistem sudah sesuai dengan apa yang diharapkan oleh pengguna 
7. Menggunakan Sistem, merupakan fase dimana perangkat lunak yang sudah di uji dan disetujui akan siap digunakan.

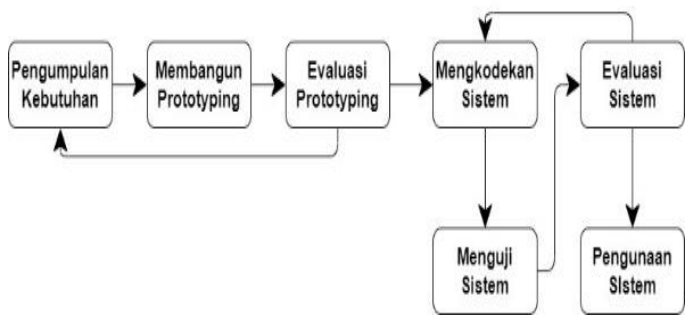

Gambar 1. Metode Prototyping sumber[10]

\subsection{Analisa Sistem}

Blockchain memiliki sifat transparan dan aman, hal ini dapat mendukung dalam pembuatan sistem pengolahan data informasi pada Pemerintahan Kota Kendal dengan menggunakan bahasa Javascript dan di implementasikan dengan framework angular.

Membuat modul dengan bahasa javascript yang berorientasi pada objek (OOP) teridiri dari class transaction, class block dan class blockchain . pembuatan fungsi hashing pada blockchain di bantu dengan modul crypto-js, lalu pembuatan genesis block atau block pertama pada sistem pengolah data informasi Pemerintah Kota Kendal. Setelah pembuatan modul selesai maka akan di implementasikan pada sistem aplikasi berbasis web dengan bantuan framework Angular.

\subsection{Perancangan Sistem}

Perancangan pada sistem ini menggunakan mode UML (Unified Modeling Language) yang merupakan spesifikasi standar dalam pembangunan sebuah sistem informasi. Diagram yang digunakan untuk merancang sistem ini merupakan use case diagram, sequence diagram, activity diagram dan class diagram[11].

\subsection{Use Case Diagram}

Use case diagram merupakan gambaran fungsionalitas yang diharapkan dalam sebuah sistem. Use case mempresentasikan sebuah interaksi yang terjadi antara sistem dengan lingkungannya. Mengacu pada hal tersebut, berikut use case dari sistem pengolah data yang aman dan transaparan dengan konsep teknologi blockchain

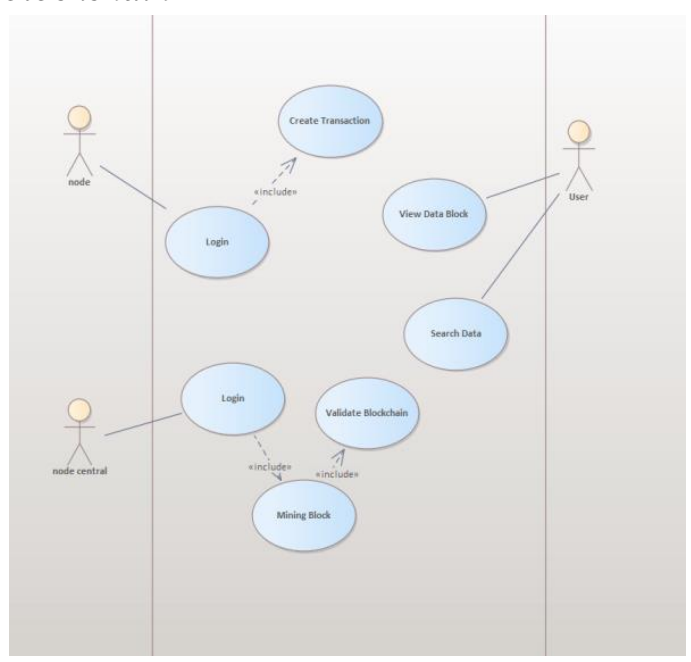

Gambar 2. Use Case Diagram

Sumber : Hasil Penelitian

Pada gambar use case diagram diatas merupakan hasil penelitian pembuatan sistem ini, dimana memiliki 3 aktor yaitu node, node central dan user, dan setiap aktor memiliki peran masing-masing. Node sebagai aktor yang melakukan penambahan data pada sistem, node central sebagai aktor yang melakukan enkripsi data yang di tambahkan ke dalam sistem, dan user sebagai penerima data.

\subsection{Class Diagram}

Class diagaram menggambarkan struktur dan deskripsi class, package dan objek beserta hubungan satu dengan yang lainnya. Dalam sebuah kelas memiliki dua komponen, yang pertama yaitu attribute yang berisi informasi yang dimiliki class dan yang kedua merupakan operation yang merupakan perilaku yang bisa dilakukan 
oleh sebuah kelas. Gambar dibawah ini merupakan perancangan dari sistem informasi yang penulis buat berdasarkan dari konsep blockchain.

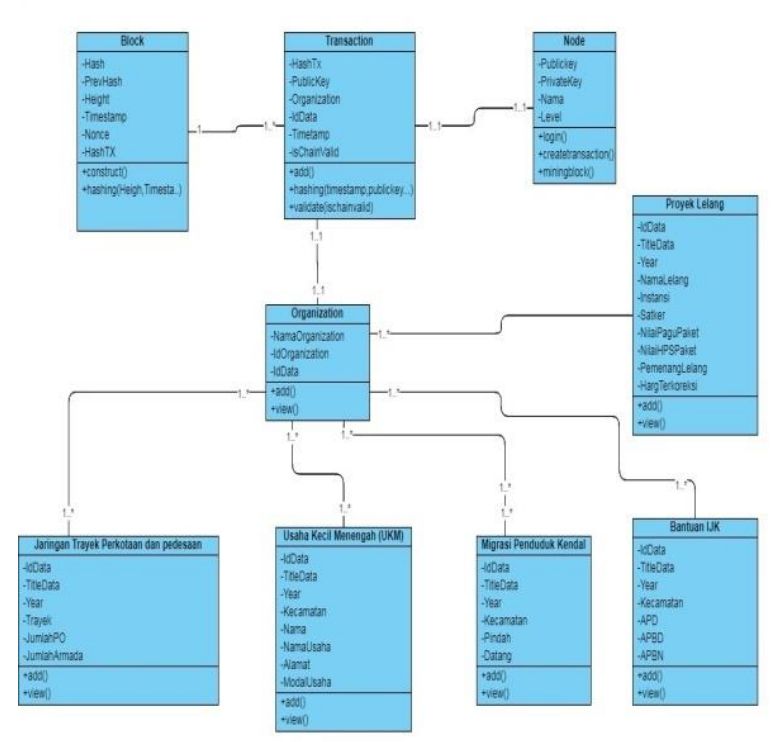

Gambar 3. Class Diagram

Sumber : Hasil Penelitian

Pada gambar class diagram di atas merupakan hasil penelitian dalam pembuatan sistem, yang mana dalam pembuatan sistem memiliki objek utama adalah block yang mana di dalam objek block tersebut berisi tentang metode keamanan dalam sebuah data yang akan digunakan dalam sistem, beserta informasiinformasi dari objek lain terutama informasi yang ada di objek transaction sebagai data transaksinya.

\subsection{Sequence Diagram}

Sequence diagram menggambarkan interaksi antar objek dan sistem berupa massage yang digambarkan terhadap waktu.

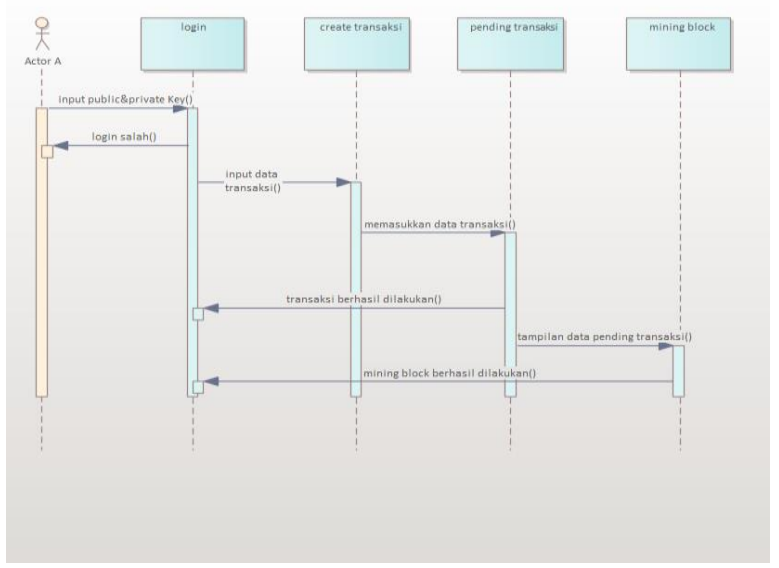

Gambar 4. Sequence Diagram

Sumber : Hasil Penelitian

Pada gambar sequence diagram diatas merupakan hasil penelitian dalam pembuatan sistem ini yang menjelaskan interaksi dari login, setelah itu membuat transaksi dan melakukan mining block sebagai tindakan enkripsi data yang ada dalam transaksi.

\subsection{Activity Diagram}

Activity diagram menggambarkan alir aktivitas yang ada dalam sistem, bagaimana alir berawal, decision terjadi dan bagaimana berakhirnya alir.

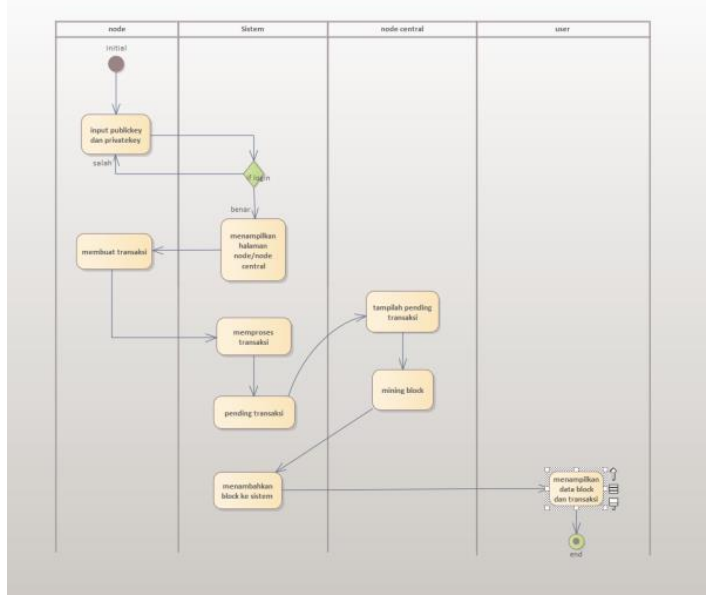

Gambar 5. Activity Diagram

Sumber : Hasil Penelitian 
Pada gambar activity diagram di atas merupakan hasil penelitian dalam pembuatan sistem, yang mana menjelaskar alir aktivitas dari aktor node, node central dan user itu sendiri terhadap sistem beserta respon dari sistem yang akan berjalan.

\section{HASIL DAN PEMBAHASAN}

\subsection{Analisis Kebutuhan Sistem}

hasil dari rancangan menjadi sebuah aplikasi sistem informasi pengolahan data menggunakan konsep teknologi blockchain membutuhkan kebutuhan lingkungan sumber daya dan implementasi basis data.

\subsubsection{Lingkuingan Sumber Daya}

Pada implementasi sistem pengolah data ini dibutuhkan beberapa aktor untuk berjalannya sistem informasi ini, adapun aktor tersebut :

1. User, aktor ini mampu menjalankan atau mengoperasikan komputer, user terlibat langsung dengan sistem informasi.

2. Node, merupakan aktor yang bisa melakukan transaksi data dari sistem informasi.

3. Node Central, merupakan aktor yang melakukan mining block sekaligus meninjau ulang transaksi data yang dikirimkan oleh node.

4. Programmer, merupakan aktor yang memiliki keahlian dalam pembuatan informasi, programmer merancang dan membangus sistem informasi pengolahan data ini. Programmer juga bertugas melakukan pemeliharaan sistem informasi.

Pembahasan terhadap hasil penelitian dan pengujian yang diperoleh disajikan dalam bentuk uraian teoritik, baik secara kualitatif maupun kuantitatif. Hasil percobaan sebaiknya ditampilkan dalam berupa grafik atau pun tabel. Untuk grafik dapat mengikuti format untuk diagram dan gambar.

\subsection{Tampilan Antarmuka Sistem}

1. Halaman Login

Halaman ini merupakan hasil penelitian sebagai batasan untuk pengguna dan di khususkan untuk aktor node/node central untuk bisa melakukan hak ases mereka.

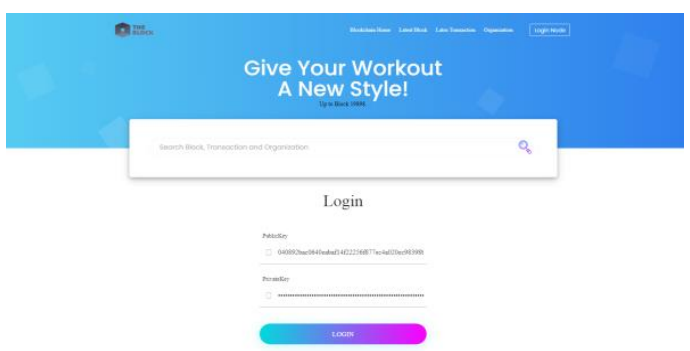

Gambar 6. Halaman Login

Sumber : Hasil Penelitian

\section{Halaman Utama}

Halaman ini merupakan hasil penelitian tampilan awal ketika mengakses sitem dengan berisi data-data yang terbaru dari sistem

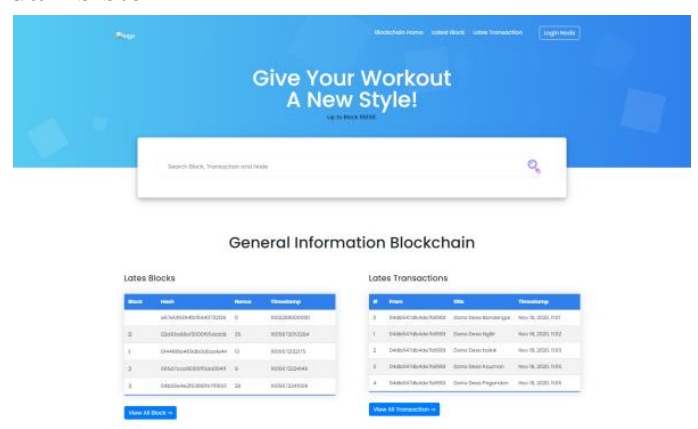

Gambar 7. Halaman Utama

Sumber : Hasil Penelitian

\section{Halaman Create Transaction}

Halaman ini adalah hasil penelitian dari sistem yang berisi form untuk melakukan transaksi yang nantinya akan disimpan di dalam block, hak akses ini di miliki oleh level node 


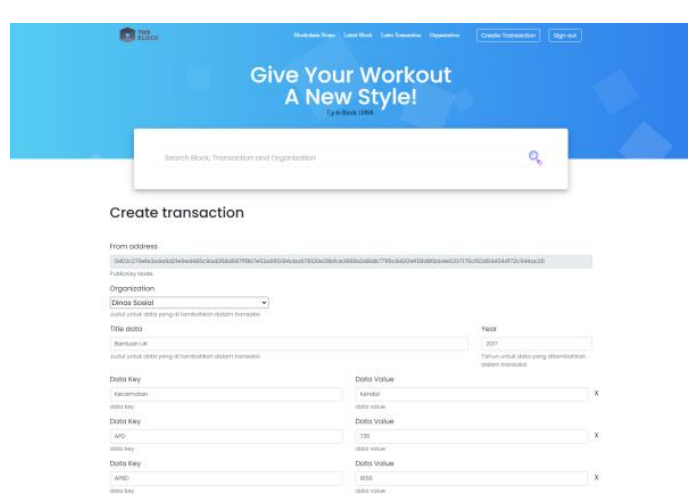

Gambar 8. Halaman Create Transaction Sumber : Hasil Penelitian

\section{Halaman Mining Block}

Halaman ini merupakan hasil penelitian halaman untuk menambahkan block baru kedalam sistem dengan beberapa transaksi data yang sudah ada

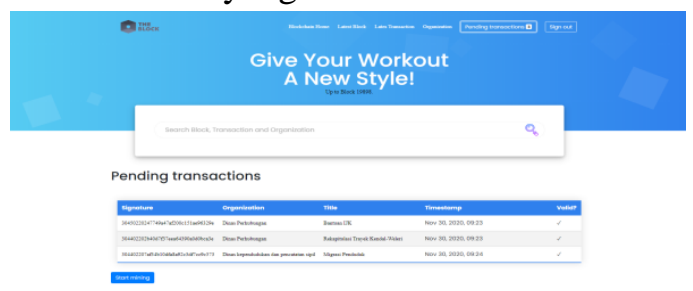

Gambar 9. Halaman Mining Block Sumber : Hasil Penelitian

\section{Halaman Detail Block}

Halaman ini merupakan hasil penelitian dimana halaman dimaksudkan untuk melihat rincian dari block yang sudah dipilih dimana berisi beberapa komponen atau field data

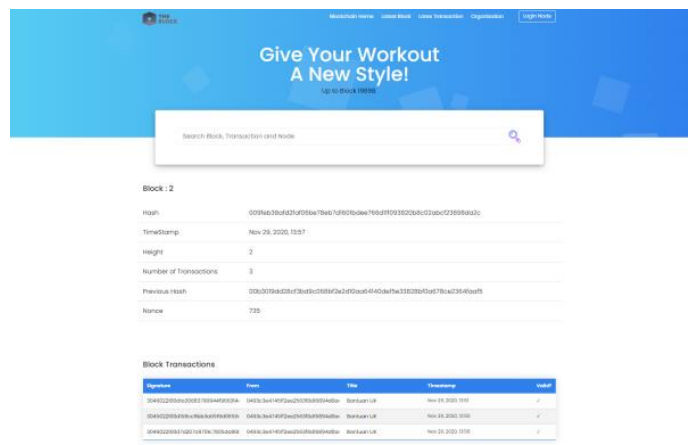

Gambar 10. Halaman Detail Block Sumber : Hasil Penelitian
6. Halaman Detail Transaction

Halaman ini merupakan hasil penelitian dimana halaman rincian data transaksi yang sudah dipilih, dimana berisi beberapa komponen atau field data.

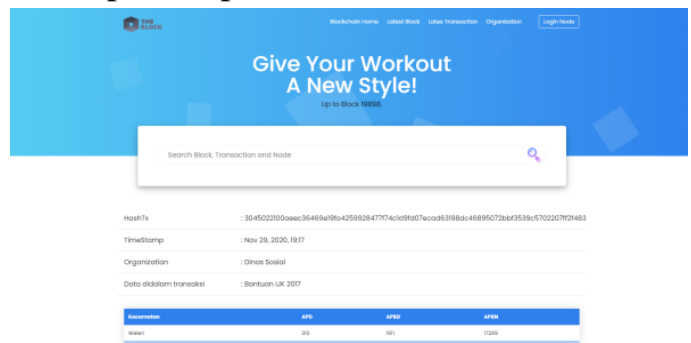

Gambar 11. Halaman Detail Transaction Sumber : Hasil Penelitian

7. Halaman Detail Organization

Halaman ini merupakan hasil peneliatan dimana halaman ini berisi rincian data organisasi dan transaksi yang terkait dengan organisasi yang dipilih, dimana berisi beberapa komponen atau field data

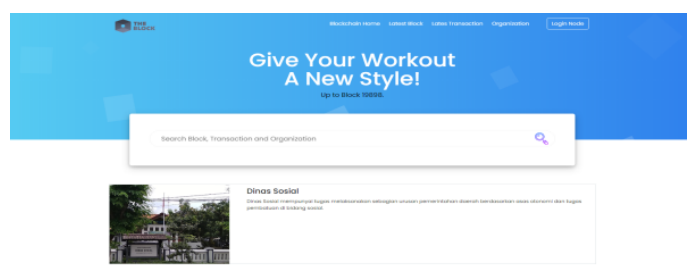

Gambar 12. Halaman Detail Organization Sumber : Hasil Penelitian

\subsection{Pengujian Sistem}

Pada pengujian ini dilakukan dengan menggunakan metode BlackBox dimana pengujian ini berfokus pada fungsionalitas atau pada output yang dihasilkan dari interekasi user dari create transaction dan mining sistem :

\section{Create Transaction}

Hasil uji create transaction dengan menggunakan metode BlackBox menghasilkan sistem create transaction yang berjalan dengan baik dan seperti yang 
diharapkan dimana transaksi yang berupa data berhasilkan dilakukan berada pada pending transaction yang nantinya akan dilakukan mining block oleh node central.

Tabel 1 Uji Create Transaction

\begin{tabular}{|l|l|l|l|}
\hline Input & Diharapkan & Output & Hasil \\
\hline Masuk & Transaksi & Transaksi & Sistem \\
kan & berhasil & berhasil & Berjal \\
data & ditambahka & ditambah & an \\
transa & $\mathrm{n}$ kedalam & kan & denga \\
ksi & pending & kedalam & $\mathrm{n}$ baik \\
& transaction & pending & dan \\
Klik & & transactio & \\
tombo & & $n$ & \\
1 buat & & & \\
transa & & & \\
ksi & & & \\
\hline
\end{tabular}

Sumber Data : Hasil Penelitian

\section{Mining Block}

Hasil uji mining block menggunakan metode BlackBox menghasilkan sistem mining block yang berjalan dengan baik dan seperti yang diharapkan dimana block ditambahkan kedalam sistem dan membentuk rantai block.

Tabel 2 Uji Mining Block

\begin{tabular}{|l|l|l|l|}
\hline nput & Diharapkan & Output & Hasil \\
\hline Klik & Block & Block & Sistem \\
minin & berhasil & berhasil & berjala \\
$g$ & ditambahka & ditambah & n \\
block & n ke dalam & kan ke & denga \\
& rantai block & dalam & n baik \\
& & rantai & \\
& & block & \\
\hline
\end{tabular}

Sumber Data : Hasil Penelitian

\section{KESIMPULAN}

Berdasarkan dari hasil dan pembahasan sistem informasi yang telah dilakukan, bisa diambil kesimpulan yaitu :

1. Teknologi Blockchain dapat membantu Pemerintah Kota Kendal menyimpan data yang transparan dan dapat di akses publik.
2. Teknologi Blockchain dapat membantu Pemerintah Kota Kendal melakukan pengolaha data secara efisien dan efektif

3. Teknologi Blockchain dapat membantu Pemerintah Kota Kendal untuk menyimpan data yang tidak bisa dimanipulasi

4. Teknologi Blockchain dapat membantu Pemerinatah Kota Kendal untuk melakukan validasi apakah data valid atau tidak valid

5. Pengujian Sistem Informasi pengolahan data pada Pemerintah Kota Kendal berjalan dengan baik

\section{SARAN}

Saran untuk penyempurnaan dan pengembangan sistem informasi serta penelitian lebih lanjut antara lain :

1. Menambah data dari organisasi pemerintah yang tidak tercantum pada sistem

2. Menambah pengembangan aplikasi berbasis mobile

3. Membuar data menjadai rest full api untuk pemanfaatan data lebih optimal.

\section{DAFTAR PUSTAKA}

[1] J. I. Mulawarman et al., "IMPLEMENTASI KRIPTOGRAFI PENGAMANAN DATA PADA PESAN TEKS , ISI FILE DOKUMEN , DAN FILE DOKUMEN MENGGUNAKAN ALGORITMA ADVANCED ENCRYPTION," vol. 10, no. 1, 2015.

[2] H. Sembiring, S. Utara, F. Y. Manik, S. Utara, and S. Utara, "Penerapan Algoritma Secure Hash Algorithm ( SHA ) Keamanan Pada Citra," vol. 4, no. 1, pp. 33-36, 2019.

[3] W. S. Stornetta, "Teknologi 
Blockchain untuk Transparansi dan Keamanan pada Era Digital," p. 6, 2020, [Online]. Available: http://repository.unmuha.ac.id/xmlui /handle/123456789/579.

[4] A. C. Nugraha, "Penerapan Teknologi Blockchain dalam Lingkungan Pendidikan," $J$. PRODUKTIF, vol. 4, no. 1, pp. 1520, 2020.

[5] H. Yulianton, R. C. N. Santi, K. Hadiono, and S. Mulyani, "Implementasi Sederhana Blockchain," Sintak, vol. 2, no. November, pp. 306-309, 2018, [Online]. Available: https://www.unisbank.ac.id/ojs/inde x.php/sintak/article/view/6635.

[6] M. U. Noor, "Implementasi Blockchain di Dunia Kearsipan: Peluang, Tantangan, Solusi atau Masalah Baru?," Khizanah alHikmah J. Ilmu Perpustakaan, Informasi, dan Kearsipan, vol. 8, no. 1, p. 81, 2020, doi: 10.24252/kah.v8i1a9.

[7] S. D. K. Hu, H. N. Palit, and A. Handojo, "Implementasi Blockchain: Studi Kasus e-Voting," J. Infra, vol. 7, no. 1, pp. 183-189, 2019.

[8] S. Haber and W. S. Stornetta, "How to time-stamp a digital document," J. Cryptol., vol. 3, no. 2, pp. 99-111, 1991, doi: 10.1007/BF00196791.

[9] R. S. Pressman, Software Engineering: A Practitioner's Approach. Boston, 2005.

[10] V. Sahfitri, "Prototype E-Katalog Dan Peminjaman Buku Perpustakaan Berbasis Mobile," $J$. Sisfokom (Sistem Inf. dan Komputer), vol. 8, no. 2, p. 165, 2019 , doi: 10.32736/sisfokom.v8i2.665.

[11] A. Winarto, "Desain E-Transkrip dengan Teknologi Blockchain," Pros. Semin. Nas. Pakar, vol. 0, no. 0, pp. 1-37.1-1.37. 6, 2019, [Online]. Available: https://www.trijurnal.lemlit.trisakti.a c.id/pakar/article/view/4176\%0Ahtt ps://www.trijurnal.lemlit.trisakti.ac.i d/pakar/article/view/4176/3316.

[12] M. H. W, "Perkembangan Enkripsi Fungsi Hash pada SHA ( Secure Hash Algorithm )," J. Ilmu Komput. dan Teknol. Inf., vol. 3, no. 2, pp. 17, 2009

[13] A. Argani and W. Taraka, "Pemanfaatan Teknologi Blockchain Untuk Mengoptimalkan Keamanan Sertifikat Pada Perguruan Tinggi," ADI Bisnis Digit. Interdisiplin J., vol. 1, no. 1, pp. 10-21, 2020, [Online]. Available: https://adijournal.org/index.php/abdi/article/vi ew/121.

[14] B. Maryanto, "Penggunaan Fungsi Hash Satu-Arah Untuk Enkripsi Data," Media Inform., vol. 7, no. 3, pp. 138-146, 2008.

[15] S. Sulastri and R. D. M. Putri, "Implementasi Enkripsi Data Secure Hash Algorithm (SHA-256) dan Message Digest Algorithm (MD5) pada Proses Pengamanan Kata Sandi Sistem Penjadwalan Karyawan," $J$. Tek. Elektro, vol. 10, no. 2, pp. 7074, 2018, doi: 10.15294/jte.v10i2.18628.

[16] H. F. Putra, W. Wirawan, and O. Penangsang, "Penerapan Blockchain dan Kriptografi untuk Keamanan Data pada Jaringan Smart Grid," J. Tek. ITS, vol. 8, no. 1, 2019, doi: 10.12962/j23373539.v8i1.38525. 